\title{
Anabases
}

ANABASES Traditions et réceptions de l'Antiquité

29 | 2019

Varia

\section{Les Horti Tauriani. Étude topographique sur la région de la Porte Majeure [1936]}

Pierre Grimal

\section{(2) OpenEdition}

Journals

Édition électronique

URL : https://journals.openedition.org/anabases/9312

DOI : 10.4000/anabases.9312

ISSN : 2256-9421

Éditeur

E.R.A.S.M.E.

Édition imprimée

Date de publication : 14 avril 2019

Pagination : 313-352

ISSN : 1774-4296

\section{Référence électronique}

Pierre Grimal, «Les Horti Tauriani. Étude topographique sur la région de la Porte Majeure [1936] »,

Anabases [En ligne], 29 | 2019, mis en ligne le 14 avril 2021, consulté le 06 novembre 2021. URL

http://journals.openedition.org/anabases/9312 ; DOI : https://doi.org/10.4000/anabases. 9312

Ce document a été généré automatiquement le 6 novembre 2021

(c) Anabases 


\section{Les Horti Tauriani. Étude topographique sur la région de la Porte Majeure [1936]}

Pierre Grimal

1 «Les Horti Tauriani, Étude topographique sur la région de la Porte Majeure » in MEFRA 53 (1936), p. 250-286. 